\title{
TEACHING VOCABULARY MASTERY TO THE PRIMARY PUPILS THROUGH ALPHABET CARDS
}

\author{
Derin Karbala \\ derinkarbala@gmail.com
}

\begin{abstract}
The paper aims at explaining how primary pupils are taught vocabulary through Alphabet Cards. The subject of this classroom action research was 20 pupils. The research was a classroom action research which was conducted in two cycles where each cycle consisted of planning, implementation, observation and reflection. The data of this research were obtained from the results of the test and observation sheet, questionnaire, field notes, during the implementation of the action. The findings of the research showed that Alphabet Cards was effective in developing primary pupils' vocabulary. The effectiveness of Alphabet Cards was shown by the improvement of pupils' score. The findings revealed that in cycle 1 there were 12 pupils who achieved minimum criteria of achievement. It means that the classical achievement was $60 \%$. In cycle 2, it showed that there were 17 of 20 pupils who achieved the minimum criteria of achievement. It means that the gain achievement was $85 \%$. Gain achievement is based on the number of pupils who get the score at least the criteria of success (70). Both of the gained and individual achievements have met the criteria of success. It can be concluded that the Alphabet cards is very effective to develop the pupils' vocabulary.
\end{abstract}

Keywords: Vocabulary, Alphabet Cards, Primary pupils

\section{INTRODUCTION}

To make pupils ready to impart in a language, they should dominate the vocabulary of the language. Vocabulary is vital in language learning and it should be learned by pupils. It is the premise of the language, in English as well as in different dialects. Vocabulary authority of the pupils can help them to convey by utilizing this language (Nation, 1990; Rolando, 2003; Sheridan and Markslag, 2017; Marzuki, 2019b).

In educating and learning exercises for school pupils, some instructing media can be utilized: like tune, games, puzzle-word, pictures, word rundown of card, and Alphabet card. These media can assist the educator with instructing pupils to dominate the English vocabulary (Harmer, 1998; Lang and Nunan, 2006; Berne \& Blachowicz, 2008; Destianingsih \& Satria, 2017; Marzuki et al., 2018; 
Marzuki, 2019a; Alek et al., 2020). Many pupils have low ability in vocabulary especially for school pupils. Even though, they have already studied English in Elementary School level. The pupils got difficult to remember the vocabulary (Marzuki, 2017; Marzuki, 2019c; Alek et al., 2020; Albana et al., 2020; Kuliahana and Marzuki, 2020). The lack of vocabulary may derive from both pupils as the learners and the teacher as the instructor. Pupils' inability in memorizing a number of words make them difficult to learn English. While teacher's inability to choose a good technique make the teacher difficult to explain material for pupils. Therefore pupils need one technique to increase their vocabulary like Alphabet cards.

The researcher picked the exploration test since she tracked down that the pupils got hard to recollect the vocabulary. The absence of vocabulary may get from the two pupils as the pupils and the educator as the teacher. Pupils' powerlessness in retaining various words make them hard to learn English. While instructor's failure to pick a decent procedure make the educator hard to clarify material for pupils. In light of the difficult assertion, the researcher made it more exact on the objective of portrayal, the analyst detailed in research address as follow:

How does Alphabet Cards in Teaching Vocabulary to the primary pupils?

\section{RESEARCH METHOD}

The plan of this exploration was CAR (Classroom Action Research). As indicated by Kemmis and Taggart, Classroom Action Research proposes the researcher to have a collective activity. Activity research is community; it includes those dependable in improving it, enlarging the teaming up bunch from those most straightforwardly improved to however many as could be allowed of those influenced by the training concerned. This exploration required the researcher and her partner plan exercise plans, get ready instructional material and media, and carry out the activity plan. To direct the exploration, the researcher and her partner started the examination from arranging, carrying out, noticing, and reflecting. The four primary exercises were called stages (Kemmis and 
McTaggart, 1988; McNiff, 1992; Nunan, 1998; Richard and Renandya, 2002; Marzuki, 2016).

\section{Results and Discussion}

The arrangement was finished regarding the examination need. It contained examination instrument in which the analyst utilized them in social affair information from the field.

To set up those instruments are critical to do to make the examination decidedly ready. Comparing to the above task, the analyst and the teammate cooperated getting ready researcher instrument, instructional materials and media too. The analyst gave some instructional materials and media which were essential for educating. In the meantime, the teammate increased perception agenda, he used to notice the instructor's presentation and pupils' reaction during the showing cycle; and other instrument, for example, assessment sheet and field notes. There were four fundamental arrangements the researcher and her partner before they did the activity. The arrangements compared to explore instruments, in which they contain perception agenda, survey, field notes, and test. Besides, to direct a smooth showing learning measure, the researcher likewise arranged showing materials and showing helps she utilized in the showing learning measure.

\section{Student's Participation in Teaching Learning Process}

Appraisal on instructing learning interaction ought to be comprehensively led by the researcher to empower the instructor to direct an exact judgment about the cycle. All-encompassing evaluation incorporates the appraisal worries about pupils' cooperation in homeroom collaboration. Pupils' support should be evaluated to ensure that they are valued each time they put forth a valiant effort. Related to appraisal on pupils' interest, pupils' investment in the encouraging learning cycle can be evaluated by utilizing gave graphs. Unmistakably to survey or to assess pupils' cooperation adds to diminish their uneasiness to exercise or any very muddled homeroom task. To survey pupils' study hall support, the researcher utilized perception agenda that contains five noticed things: eagerness, inspiration, interest, reaction, and progress. Those things were noticed and surveyed by the partner. 


\section{Student's Performance in Teaching Learning Process}

Pupils' presentation in the instructing learning measure was addressed by five segments in which the pupils were surveyed. It was by reason arranged by the researcher to see the distinction in pupils' presentation from one gathering to another. Unmistakably to survey or to assess pupils' exhibition adds to lessening their nervousness to exercise or any very confounded study hall task.

The parts that the analyst utilized them as pointers to evaluate pupils' exhibition in the instructing learning measure are understudy's energy, inspiration, premium, reaction, and pupils' advancement. The five segments were deliberately seen to ensure that the pupils have progress in study hall execution from one gathering to other gathering.

The aftereffect of the examination toward pupils' homeroom execution will be clarified as follows: (1) Pupils' energy toward the showing learning measure in (a) the greater part of the understudy in gathering 1 and 2 cycle I were in center class; (b) the vast majority of the understudy in gathering 3 cycle I were in high classification, (c) meeting 1, 2, and 3 cycle II were in high classification. From the information introduction, it tends to be presumed that the pupils have an improvement as far as their eagerness when they were in the subsequent gathering; and they could remain on the improvement up to meeting 3 . It is a result of the specialist's treatment where she clarified the assignment or gave guidance utilizing English, the instructor expected to disclose it in Indonesian to forestall to pupils misconstruing the data given.

(2) The investigation on pupils' inspiration shows that (a) meeting 1, 2, and 3 cycle I were in center class; (b) meeting 1 and 3 cycle II were in center classification; (c) meeting 2 cycle II were in high class. From the depiction, it tends to be deciphered that the pupils were roused to join the class. They contended to stand out enough to be noticed to be given undertaking to finish. (3) The discovering worries with understudy's advantage clarifies that gathering (a) 1, 2 , and 3 cycle I were in center class; (b) meeting 1, 2, and 3, cycle II were in high classification. The discoveries identified with pupils' advantage all through homeroom gatherings uncover a distinction. In the event that the pupils were in 
the center class in regards to their advantage in the primary cycle; it is not the same as the subsequent cycle. Since the specialist found that there was any critical advancement in interest when they were in the subsequent cycle. (4) Pupils' reaction toward the instructing learning measure was one of the parts that the researcher saw during showing learning measure. The consequence of perception shows that (a) meeting 1 cycle I is in low classification; (b) meeting 2, and 3 cycle I were in center classification; (c) meeting 1 and 2 cycle II were in center class; and (d) meeting 3 cycle II were in high classification. It appeared to be that the pupils didn't have any unconstrained reaction toward instructor's guidance, given exercise until they were in the second gathering of cycle I. They accomplished high class worried to reaction when they were at meeting 3 cycle II. The analyst sees that this sort of progress is ordered slothful. (5) It was discovered that understudy's advancement changed from one gathering to another; meeting 1 cycle $I$ is in low classification; (b) meeting 2 and 3 cycle I were in center classification; (c) meeting 1 and 2 cycle II were in center classification; and (d) meeting 3 cycle II were in high class. From the portrayal over, the consequence of examination can be reasoned that the pupils accomplished the pick of progress when they were in the second gathering of cycle I. It is a direct result of the researcher's treatment on giving more opportunity to the pupils for asking explanation when they actually don't see yet about the assignment.

\section{Pupils' improvement}

The pupils' improvement in vocabulary through Alphabet cards were investigated and analyzed through evaluation phase of the teaching learning process. The researcher focused on the three criteria of success in which she needed to analyze at the end of cycle. In order to provide better understanding toward the findings, the result of analysis is going to be elaborated as follows:

\section{Meetings 1, 2, and 3, in cycle I}

To look at the three principles of accomplishment, the researcher utilized Alphabet cards, discernment enlistment, and field notes. The delayed consequence of examination was that from the essential preliminary of the cycle 1 it was found there were ten of 35 pupils who got "incredible" score and four pupils who got 
"brilliant" score. It inferred that the pupils' productive rate that got accomplishment level from the essential preliminary of cycle I had not now meet the models of achievement. Since, the rate approach used formula 12x100\%:20= $60 \% .12$ was the amount of pupils who got accomplishment ability; 20 was the amount, in light of everything, and 100 is the deviation scale. On the other hand, the degree of study lobby accomplishment should be $70 \%$ of the amount of pupils.

At that point, the score of fourteen pupils were more than 70. It was not representative enough for the expert to conclude that the standards of progress have been refined since the models of accomplishment for particular pupils should be 70. Thusly, toward the day's end, the expert battled the models of progress will be refined if most of pupils achieve score 70 or over it and there are at any rate $70 \%$ from outright pupils got accomplishment level. Besides, solitary score in any case was to condemn the pupils' achievement only. There are a couple of reasons why the pupils couldn't show up at the principles of accomplishment in cycle I, to be explicit: the expert didn't explain the rules until the whole of the pupils see well, even she offered freedom to the pupils for asking clarification yet the chance was not cover all pupils who required the clarification.

The pupils' interest in learning measure was recognized through examination lobby works out. Premium as a sort of learning measure was researched emotionally. The result of insight shows that the pupils were viably checking out investigation corridor works out.

\section{Meetings 1, 2, and 3 in cycle 2}

The aftereffect of investigation toward assessment on cycle II gathering 3 evoked the critical advancement on pupils' vocabulary. During that time test in cycle II; it was discovered that there were 32 pupils who got "achievement" capability. It implies that the quantity of pupils who got "achievement" from the second assessment of cycle II has met the rules of progress; in light of the fact that the rate approach utilizes recipe $17 \times 100 \%: 20=85 \% .17$ is the quantity of pupils who get "achievement" capability; 20 is the quantity, everything being equal, and 100 is the deviation scale. Since the quantity of pupils who got "achievement" 
capability in excess of a portion of the complete number of pupils (85\%), so it is reasoned that the measures of homeroom accomplishment has been accomplished.

In the interim the higher score of 29 pupils more than 70 . It tends to be deciphered that it is totally sensible for the researcher to decide that the models of accomplishment have been accomplished since the measures of achievement for singular pupils ought to be 70 ; in addition there were 29 pupils who got at any rate 70 so the number has addressed all class members.

There are a few reasons why the pupils could arrive at the measures of accomplishment in cycle II, in particular:

1. The researcher set the time relatively for every one of the exercises done.

2. When asking the pupils for turn, the educator ought allow to specific pupils as well as others pupils relatively.

3. In clarifying the errand or giving guidance utilizing English, the instructor disclosed it in Indonesian to forestall to pupils misconstruing the data given.

\section{CONCLUSIONS}

In view of the aftereffect of this homeroom activity research, the analyst closed as follows: By carrying out the Alphabet cards strategy, the pupils were not trouble to recall vocabulary given. We could find in the principal test, the pupils' improvement arrived at $60 \%$ of 12 pupils. In the meantime, in the subsequent test, pupils' improvement accomplished $85 \%$ of 17 pupils. The instructing learning exercises that were utilized in this strategy had the option to create understudy' energy, inspiration, premium, reaction, and progress in joining the class.

\section{REFERENCES}

Albana, H., Marzuki, A. G., Alek, A., \& Hidayat, D. N. (2020). Cohesive Devices in Student's Writing (A Discourse Analysis on Argumentative Text). Jurnal Pendidikan Humaniora, 8(1), 6-11.

Alek, A., Marzuki, A. G., Farkhan, M., \& Deni, R. (2020). Self-Assessment in Exploring EFL Pupils' Speaking Skill. Al-Ta lim Journal, 27(2), 208-214.

Alek, A., Marzuki, A. G., Farkhan, M., Surahman, D., Daryanto, D., \& Febrianto, S. (2020). Computer Based Testing in Senior High School on National Examination. Indonesian Journal of Learning Education and Counseling, 2(2), 204-210. 
Berne, J. I., \& Blachowicz, C. L. (2008). What reading teachers say about vocabulary instruction: Voices from the classroom. The reading teacher, 62(4), 314-323.

Celce. M. and Murcia, 2001. Teaching English as a second or Foreign Language. United States . (Third Edition).

Destianingsih, A., \& Satria, A. (2017). A study on the effectiveness of using alphabet cards game in teaching vocabulary for commercial business administration pupils. In UAD TEFL International Conference (Vol. 1, pp. 54-64).

Harmer, J. 1998. How to Teach English. Cambridge. Pearson Longman

Kemmis, S. and McTaggart, R. 1988. The Action Research Planer. Australia. Deakin University.

Kuliahana, A., \& Marzuki, A. G. (2020). Repetition Technique in an EFL Speaking Class in Islamic Higher Education in Indonesia. Academic Journal Perspective: Education, Language, and Literature, 8(1), 20-28.

Lang, H. R. and Nunan, D. 2006. Models, Strategies, and Methods for Effective Teaching. United States. Pearson.

Marzuki, A. G. (2019a). The Implementation of SQ3R Method to Develop Pupils' Reading Skill on Islamic Texts in EFL Class in Indonesia. Register Journal, 12(1), 49-61.

Marzuki, A. G. (2019b). The Roles of School Principal Leadership in Developing English Teachers' Creativities in Palu. Al-Ta lim Journal, 26(3), 267-279.

Marzuki, A. G. (2019c). Utilizing Recorded English Dialogues in Teaching English Word Stress to Islamic Higher Education Pupils in Indonesia. Jurnal Pendidikan Islam, 5(1), 53-64.

Marzuki, A. G., Alim, N., \& Wekke, I. S. (2018). Improving the reading comprehension through cognitive reading strategies in language class of coastal area in indonesia. In IOP Conference Series: Earth and Environmental Science, 156(1), 012050). IOP Publishing.

Marzuki, A.G. (2016). Utilizing cooperative learning in islamic college pupils' classroom, IJEE (Indonesian Journal of English Education), 3(2), 123-139.

Marzuki, A.G. (2017). Developing speaking skill through oral report in an efl class in indonesia, Al-Ta'lim Journal, 24(3), 243-254.

McNiff, J. 1992. Action Research: Principle and Practice. New York. Chapman and Halls.

Nation, P. 1990. Teaching and Learning Vocabulary. Boston, Massachusetts: Heinle \& Heile Publishers. A division of Wadsworth, Inc.

Nunan, D. 1998. Research Methods in Language Learning. Cambridge University Press, Cambridge.

Richard, J. and Renandya, A. 2002. Methodology in Language Teaching. Cambridge University Press, Cambridge.

Rolando, M. 2003. Teaching your Kids through Alphabet Cards. (Online) http://www.reading-with kids.com/Alphabet Cards.html, accessed on April $2,2011$.

Sheridan, R., \& Markslag, L. (2017). Effective Strategies for Teaching Vocabulary: An Introduction to Engaging Cooperative Vocabulary Card 
Activities. PASAA: Journal of Language Teaching and Learning in Thailand, 53, 214-229. 